\title{
Peningkatan Kecerdasaan Logika Matematika Anak melalui Bermain Kartu Angka Kelompok B di TK Pembina Bangkinang Kota
}

\author{
Mufarizuddin ${ }^{凶}$ \\ Prodi PGSD Fakultas Ilmu Pendidikan \\ Universitas Pahlawan Tuanku Tambusai Riau
}

\begin{abstract}
Abstrak
Penelitian ini di latarbelakangi belum berkembangnya kemampuan kecerdasan logika matematika anak kelompok B TK Pembina Bangkinang Kota. Berdasarkan latar belakang masalah yang telah dipaparkan, maka dapat dirumuskan masalah penelitian ini, Bagaimanakah peningkatan kemampuan kecerdasaan logika matematika anak kelompok B melalui permainan kartu angka di TK Pembina Bangkinang Kota? Adapun tujuan penelitian ini adalah untuk mengetahui peningkatan kemampuan kecerdasaan logika matematika melalui permainan kartu angka pada kelompok B di TK Pembina Bangkinang Kota. Sebagai subjek dalam penelitian ini adalah anak kelompok B dan guru TK Pembina tahun pelajaran 2015/2016 dengan jumlah anak sebanyak 20 orang. Sedangkan yang menjadi objek adalah kemampuan kecerdasaan logika matematika anak kelompok B melalui permainan kartu angka. Tahapan-tahapan yang dilalui dalam penelitian tindakan kelas, yaitu : 1) Perencanaan/Persiapan tindakan, 2) Pelaksanaan Tindakan, 3) Observasi, dan. 4) Refleksi. Sumber data penelitian ini adalah anak kelompok B TK Pembina Bangkinang Kota, guru dan dokumen. Pengumpulan data menggunakan observasi, tes dan dokumentasi. Analisis data menggunakan teknik deskriptif persentase. Hasil penelitian menunjukkan bahwa melalui kartu angka dapat meningkatkan kemampuan kecerdasaan logika matematika di kelompok B TK Pembina Bangkinang Kota.
\end{abstract}

Kata kunci : kecerdasaan logika matematika, kartu Angka

\begin{abstract}
This research is in background not yet developed ability of logic mathematics intelligence of child of group B TK Pembina Bangkinang Kota. Based on the background of the problems that have been exposed, it can be formulated problem of this research, How to improve the ability of logic mathematics intelligence of group B through the game of card number in TK Pembina Bangkinang Kota? The purpose of this study is to determine the enhancement of the ability of logic mathematical intelligence through the game of number cards in group B in TK Pembina Bangkinang Kota. As the subjects in this study are the children of group B and teachers kindergarten coach 2015/2016 school year with the number of children as many as 20 people. While the object is the ability of logic mathematical intelligence of group B through the game of a number card. The steps taken in classroom action research are: 1) Planning / Preparing for action, 2) Implementation of Action, 3) Observation, and 4) Reflection. The data sources of this research are children of group B TK Pembina Bangkinang Kota, teachers and documents. Data collection uses observation, tests and documentation. Data analysis using descriptive technique percentage. The results showed that through the card number can improve the ability of logic mathematical intelligence in group B TK Pembina Bangkinang Kota.
\end{abstract}

Keywords: logic mathematical intelligence, Numeric cards

@ Jurnal Obsesi Prodi PG-PAUD FIP UPTT 2017

$\square$ Corresponding author :

Address : Perumahan Attaya 1 Ridan Bangkinang

Email : zuddin.unimed@gmail.com

ISSN 2356-1327 (Media Cetak)

ISSN 2549-8959 (Media Online) 


\section{PENDAHULUAN}

Pendidikan Anak Usia Dini merupakan pendidikan yang sangat mendasar dan sangat menentukan bagi perkembangan anak dikemudian hari. Menurut UU No. 20 Tahun 2003 pasal 1 ayat 14 menyatakan bahwa Pendidikan Anak Usia Dini adalah suatu upaya pembinaan yang ditujukan sejak lahir sampai usia enam tahun yang dilakukan dengan pemberian rangsangan pendidikan untuk membantu pertumbuhan dan perkembangan jasmani dan rohani agar siap memasuki pendidikan yang lebih lanjut. Salah satu bentuk pendidikan anak usia dini adalah Taman kanak-kanak. TK merupakan lembaga yang memberikan layanan pendidikan bagi anak usia dini pada rentang usia 4-6 tahun. Pada masa ini merupakan masa emas perkembangan dimana terjadi peningkatan luar biasa pada perkembangan anak yang tidak terjadi pada periode berikutnya. Para ahli menyebutnya sebagai usia emas perkembangan (Golden age). (Permendiknas, 2003)

Pendidikan bagi anak usia dini adalah pemberian upaya untuk menstimulasi, membimbing, mengasuh dan pemberian kegiatan pembelajaran yang akan menghasilkan kemampuan dan ketrampilan anak. Pendidikan anak usia dini merupakan salah satu bentuk penyelenggaraan pendidikan yang menitikberatkan pada peletakan dasar ke arah pertumbuhan dan perkembangan fisik (koordinasi motorik halus dan kasar), intelektual, kecerdasan kognitif atau kecerdasan merupakan suatu proses mental sehingga tidak hanya sekedar kemampuan yang terkait dengan hal akademis.

Howard Gardner menyebutkan bahwa kecerdasan tidak bersifat tunggal, tapi majemuk atau disebut kecerdasan majemuk (multiple intelligence). Kecerdasan majemuk terdiri dari 8 macam kecerdasan yaitu Kecerdasan Bahasa, Kecerdasan Logika-Matematika, Kecerdasan Visio- Spasial, Kecerdasan Kinestetik, Kecerdasan Musik, Kecerdasan Intrapersonal, Kecerdasan Interpersonal, dan Kecerdasan Natural. Tiap kecerdasan ini ada yang menonjol dan ada pula yang kurang menonjol pada individu. Pada anak usia 0 sampai 72 bulan, kecerdasan yang menonjol belum terlalu terlihat, mengoptimalkan setiap aspek kecerdasan pada anak merupakan hal yang dapat dilakukan. Optimaliasai dapat dilakukan dengan pemberian berbagai stimulasi. Setiap stimulasi yang diberikan tentunya harus bertujuan dan disesuaikan dengan usia perkembangan dari anak. Stimulasi yang diberikan juga tidak hanya yang bertujuan meningkatkan kognisi tetapi juga sosioemosional serta sensorik dan motorik anak. (Peraturan menteri Kesehatan Republik Indonesia, 2015).

Pedoman Stimulasi Anak Berbasis Kecerdasan Majemuk memberikan gambaran mengenai stimulasi pada anak yang berbasis kecerdasan majemuk. Di dalam pedoman ini, stimulasi dibedakan berdasarkan tiga kelompok usia, yaitu 0 24 bulan, 25 - 42 bulan, dan 43 - 72 bulan. Sedangkan stimulasi yang diberikan bersifat holistik bagi anak, yaitu stimulasi untuk perkembangan fisik sensorik dan motorik, kognitif atau kecerdasan dan sosioemosional. Setiap stimulasi di dasarkan pada teori kecerdasan majemuk dengan pengharapan diperoleh kecerdasan optimal dari tiap macam kecerdasan.

Memberikan stimulasi kognitif pada anak merupakan bagian dari usaha mencerdaskan bangsa. Metode stimulasi kognitif merupakan bagian dari sebuah strategi pembelajaran untuk mencapai tujuan optimalisasi fungsi kognitif anak. Prinsip stimulasi merupakan bantuan khusus yang mutlak perlu diberikan pada semua anak bila ingin anak berkembang optimal. Stimulasi yang dilakukan harus sesuai dengan tujuan. Stimulasi kognitif pada anak dilakukan dengan tujuan mengoptimalkan kecerdasan majemuk (multiple intellegence) anak.

Kecerdasan logika matematika adalah kemampuan untuk mengenal warna dan bentuk secara efektif guna meningkatkan keterampilan mengelolah angka serta kemahiran mengguakan logika atau akal sehat. Istilah kecerdasan logika matematis (math-logical intelligence) merujuk pada pemahaman paling populer 
dalam soal logika, beberapa ahli psikologi yang berkecimpung dalam bidang pendidikan mendefinisikan Intelektual atau kognitif dengan berbagai peristilahan. (Suhaidah, 2014)

Kecerdasan logika matematik berkaitan dengan perkembangan kemampuan berpikir sistematis, menggunakanangka, menghitung, menemukan hubungan sebab akibat, dan membuat klasifikasi. Anak yang mempunyai kelebihan dalam kecerdasan logika matematika, tertarik memanipulasi lingkungan serta cenderung menerapkan strategi coba ralat, mereka suka mendugaduga dan memiliki rasa ingin tahu yang besar (Hartini, 2003).

Jadi kecerdasan logika-matematika adalah kemampuan untuk melihat, memahami angka,konsep bentuk, pola serta memecahkan masalah sederhana.

a. Tujuan kecerdasan logika-matematika tujuan umum permainan kreatif PAUD untuk melatih kecerdasan logikamatematika adalah :

1) Mengembangkan kemampuan mengurutkan sesuai ciri tertentu

2) Mengembangkan kemampuan membilang, menyebutkan angka 1sampai 10

3) Mengembangkan kemampuan perkiraan ukuran seperti: banyaksedikit, besar-kecil dan panjangpendek

4) Merangsang kemampuan mengenali pola

5) Merangsang kepekaan strategi

6) Merangsang kemampuan mengenali bentuk-bentuk geometri.

b. Tahapan-tahapan Pembelajaran Matematika

1) Tingkat pemahaman konsep dimana anak akan memahami konsep melalui pengalaman beraktivitas bermain dengan benda-benda kongkrit.

2) Tingkat transisi proses berpikir yang merupakan masa peralihan dari pemahaman kongkrit menuju pengenalan lambang yang konkrit, dimana benda kongkrit itu masih ada dan mulai dikenalkan bentuk
lambangnya.Hal ini harus dilakukan guru secara bertahap sesuai dengan laju dan kecepatan kemampuan anak yang secara individual berbeda.

3) Tingkat lambang bilangan tahap terakhir di mana anak diberi kesempatan untuk mengenal dan memvisualisasikan lambang bilangan atas konsep kongkrit yang telah mereka pahami. Ada saat di mana mereka masih menggunakan alat kongkrit hingga mereka melepaskannya sendiri.

c. Faktor yang Mempengaruhi Kecerdasan Logika-Matematika

1) Faktor Herediter ( faktor bawaan dari keturunan ). Semua anak mempunyai gen pembawa kecerdasan dengan kadar yang dapat berbeda-beda.

2) Faktor Lingkungan Semenjak lahir anak mulai berinteraksi dengan lingkungan tempat hidupnya. Ketika panca indera mulai berfungsi anak akan semakin banyak berhubungan dengan lingkungan. Lingkungan berpengaruh besar pada kecerdasan anak.

3) Asupan Nutrisi pada Zat Makanan Nutrisi merupakan salah satu faktor yang mendukung perkembangan kecerdasan anak. Jumlah nutrisi harus memenuhi batas kemampuan tubuh untuk menyerapnya dalam keadaan yang berlebihan, nutrisi tersebut tidak dapat diserap bagaimana fungsinya. Bahkan dapat menimbulkan efek samping yang kurang baik.

4) Aspek kejiwaan Kondisi emosi bernilai penting dalam menumbuhkan bakat dan minat anak sehingga akan sangat berpengaruh pada tingkat kecerdasan anak.

d. Indikator Kecerdasan LogikaMatematika

1) Membilang dengan menunjuk benda (mengenal konsep bilangan dengan benda 1 - 5) seperti anak 
menyusun balok membentuk menara eiffel sambil mengitung dengan urut dari yang kecil sampai besar.

2) Menghubungkan/memasangkan lambang bilangan dengan benda sampai 5 anak mengambil benda sesuai angkanya

3) Mengelompokkan bentuk-bentuk geometri (mengelompokkan balok berdasarkan bentuk-bentuk geometri

4) Mengelompokkan benda dengan berbagai cara menurut ukuran, bentuk, warna, jenis, dan lain-lain. (Eny Purwaningtyastuti, 2012)

Salah satu kecerdasan yang berpengaruh penting dalam kehidupan anak yaitu kecerdasan logika matematika, kecerdasan logika matematika sudah lama di unggulkan dan diakui sejak lama, banyak tes psikometrik memberikan ruang yang luas untuk kecerdasan ini, dan menjadi salah satu indikator terkuat dalam menilai anak didik yakni bisa dikatakan cerdas dan tidak cerdas, setiap pendidik PAUD mutlak menstimulasi kecerdasan logika matematika karena keberhasilan stimulasi tersebut akan memberikan dampak yang sangat luas dalam perkembangan anak karena hampir semua aktifitas kehidupan dan berkarier tidak lepas dari kecerdasan ini.

Kondisi yang dianjurkan para pakar pendidikan untuk melejitkan kecerdasan logis-matematis adalah kondisi dimana anak mampu menggunakan angka dan logika matematika untuk memahami suatu pola tertentu yang muncul dalam hidup, seperti pola pikir, pola angka, pola visual, dan pola warna. Mencintai matematika bagi anak-anak dengan pendekatan permainan matematika sesuai dengan tujuan kurikulum pendidikan matematika TK/RA, yaitu:

1) Kemampuan kognitif, yaitu anak dapat mengenal konsep bilangan dengan benda-benda 1-10

2) Menghubungkan/memasangkan lambang bilangan dengan benda-benda

3) Mengenal konsep matematika sederhana, yaitu penambahan dan pengurangan
4) Menggabungkan dua kumpulan benda

Menurut Hurlock seiring dengan perkembangan pemahaman bilangan permulaan ini menyatakan bahwa konsep yang mulai dipahami anak sejalan dengan bertambahnya pengalaman yang dialami anak, diantaranya konsep bilangan.(Asiyah, 2013)

Konsep bilangan dapat dikenalkan dengan cara bermain karena bermain adalah cara belajar yang paling sesuai dengan karakter anak usia dini. Dalam bermain anak memiliki nilai kesempatan untuk mengekspresikan sesuatu yang ia rasakan dan ia pikirkan. Anak mempraktikkan keterampilan dan mendapatkan kepuasan dalam bermain, yang berarti mengembangkan dirinya sendiri.(Fauziddin, 2017)

Lebih lanjut (Puspitasari, 2012) mrnyatakan Salah satu prinsip pembelajaran anak usia dini yaitu anak belajar melalui bermain. Bermain merupakan pekerjaan bagi anak, apa yang dilakukan anak semuanya adalah bermain, hal ini karena bermain adalah sesuatu yang menyenangkan, tanpa paksaaan, serta bebas untuk memilih.

Menurut Susanto (Asiyah, 2013) permainan flashcard (kartu angka) berdampak positif terhadap peningkatan kemampuan berhitung permulaan, karena permainan kartu ini dapat merangsang anak lebih cepat mengenal angka, membuat minat anak semakin menguat dalam menguasai konsep bilangan, serta merangsang kecerdasan dan ingatan anak, mampu mengembangkan kemampuan karena anak dapat memiliki konsep berhitung dengan baik dan anak dapat mengembangkan segenap potensi yang ada pada dirinya sesuai dengan kemampuanya seoptimal mungkin, anak juga akan banyak belajar mengenai urutan bilangan dan pemahaman konsep angka dengan baik.

Penggunaan kartu angka terhadap kemampuan berhitung permulaan, diantaranya anak mampu mengembangkan kemampuan kognitifnya dengan baik, anak memiliki konsep berhitung dengan baik, dan anak dapat mengembangkan segenap potensi yang dimiliki sesuai dengan 
kemampuannya. Hal ini penting karena perkembangan anak harus sesuai dengan taraf perkembangan.

Keuntungan Penggunaan Kartu Angka (Flashcard) : 1) Dapat merangsang anak lebih cepat mengenal angka. 2) Membuat minat anak semakin menguat dalam menguasai konsep bilangan. 3) Merangsang kecerdasan dan ingatan anak. 4) Mampu mengembangkan kemampuan kognitif. 5) Memiliki konsep berhitung dengan baik. 6) Anak akan mengembangkan segenap potensinya yang ada pada dirinya. 7) Anak akan belajar mengenal urutan bilangan dan pemahaman konsep angka dengan baik. 8) Anak akan lebih mudah memahami konsep penambahan dan pengurangan dengan baik dengan menggunakan gambar dan benda.

Kekurangan Penggunaan Kartu Angka (Flashcard) : 1) Sulit menampilkan gerak dalam media gambar. 1) Biaya yang dikeluarkan akan banyak apabila ingin membuat gambar yang lebih bagus dan bervariasi. 2) Berbagai unit-unit pelajaran dalam media gambar harus dirancang sedemikian rupa sehingga tidak terlalu banyak dan membosankan anak. 3) Jika tidak dirawat dengan baik, media gambar akan mudah rusak dan hilang. 4) Memerlukan kreatifitas dari guru yang tinggi untuk memberikan inovasi dari media gambar sehingga tidak membosankan anak. Kognitif adalah suatu proses berfikir, yaitu kemampuan individu untuk menghubungkan, menilai dan mempertimbangkan suatu kejadian atau peristiwa. Proses kognitif berhubungan dengan berbagai minat terutama sekali ditujukan kepada ide-ide dan belajar (Asiyah, 2013).

Menurut Piaget (Asiyah, 2013) perkembangan kognitif mempunyai 4 aspek yaitu : kematangan merupakan pengembangan dari susunan syaraf, pengalaman merupakan hubungan timbal balik antara organisme dan lingkungan, transmisi merupakan pengaruh yang diperoleh dalam hubungan dengan lingkungan sosial, ekuilibrasi kemampuan yang mengatur dalam diri anak agar ia selalu mampu mempertahankan keseimbangan dan penyesuaian diri terhadap lingkungan.

Adapun materi pengenalan konsep bilangan pada Anak Usia Dini terdapat dalam kurikulum 2007 yang meliputi : membilang, menyebutkan urutan bilangan dari 1 sampai 10 , membuat urutan bilangan 1-10 dengan benda-benda, menghubungkan dan memasangkan lambang bilangan dengan benda-benda hingga 10 (anak tidak disuruh menulis). Masalah yang terbanyak dialami anak adalah kebanyakan mereka belum memahami bentuk-bentuk angka, sehingga kondosi tersebut berdampak pada mereka dalam mengurutkan angka 1-10 dan jumlah bendanya bertdasarkan perenungan terhadap proses pembelajaran selama ini yang disebabkan belum maksimal guru dalam memberi bimbingan dan pendekatan secara persuasive terhadap anak-anak, dan masih cenderung menggunakan cara klasikal. Upaya yang telah dilakukan guru belumlah cukup untuk memberikan pemahaman konsep bilangan/angka, karena masih banyak yang salah dalam pemahaman lambang bilangan seperti angka 6 dan 9.

Berdasarkan pengamatan penulis tahun ajaran 2015/2016 masih terdapat $75 \%$ anak kelompok B yang rendah kemampuannya dalam mengenal konsep bilangan seperti pada kegiatan pembelajaran membuat urutan bilangan 1 sampai 10 dengan alat bantu batu (kerikil) masih terdapat anak yang salah dalam mengurutkan bilangan. Hal ini disebabkan antara lain pembelajaran yang dilaksanakan guru tentang konsep bilangan di TK, menggunakan metode pembelajaran yang kurang variatif.

Fakta lain adalah rendahnya kemampuan anak dalam mengenal konsep bilangan dan lambangnya. Hal ini disebabkan oleh rendahnya minat dan semangat belajar anak pada pembelajaran yang diterapkan. Faktor minat dan semangat belajar seorang anak dalam mengenal konsep bilangan dan lambangnya turut berpengaruh terhadap kemampuan perkembangannya pada bidang pengembangan yang lain, seperti: kognitif, fisik, motorik dan seni. 
Di sisi lain, guru menemui kendala dalam pembelajaran ketika mengenalkan konsep bilangan dan lambangnya kepada anak, perhatian anak sangat kurang. Anak-anak gelisah dan tidak tahan duduk dalam waktu balajar berlangsung. Dengan kata lain, anak-anak tidak mempunyai konsentrasi yang baik dalam mengikuti kegiatan pembelajaran. Oleh sebab itu, guru harus mengamati anak dengan cermat dan menentukan kemampuan, kebutuhan, minat dan cara belajar masing-masing anak. Proses belajar terjadi karena adanya interaksi antara pemikiran anak dan pengalamannya dengan bahan-bahan ajar, gagasan-gagasan, dan orang-orang yang ada di sekitarnya. Pengalamanpengalaman ini harus cocok dengan tingkat kemampuan dan kebutuhan anak yang sedang berkembang.

$$
\text { Berbagai cara yang telah }
$$

diupayakan dalam pembelajaran mengenal konsep bilangan dan lambangnya ini misalnya dengan menggunakan metode ceramah, tanya jawab, pembimbingan anak, pemberian tugas namun pada kenyataannya hasil belajar yang dicapai anak masih rendah. Hal ini dapat dibuktikan bahwa anakanak belum mampu mengingat konsep bilangan dan lambangnya pada saat kegiatan pembelajaran.

Untuk meningkatkan kemampuan anak mengenal konsep bilangan dan lambangnya, maka peneliti mencoba menggunakan strategi pembelajaran melalui kegiatan kartu angka. Hal ini dapat menarik minat dan semangat belajar anak mengenal konsep bilangan dan lambangnya. Setiap konsep bilangan dan lambangnya yang dipelajari, disertai gambar yang menarik lalu menyampaikan atau mengenalkannnya kepada anak. Anak menjadi terkesan dan bersemangat dalam belajar. Dengan demikian, anak mudah mengingat setiap konsep bilangan dan lambangnya yang dipelajari. Diharapkan setelah semua konsep bilangan dan lambangnya dikenal, memudahkan anak untuk menghitung pada waktu yang akan datang.

Sehubungan dengan hal tersebut, maka penulis termotivasi untuk mengadakan penelitian tindakan kelas dengan judul: "Peningkatan Kecerdasaan Logika-Matematika Anak Melalui Bermain Kartu Angka Kelompok B di TK Pembina Bangkinang Kota".

Tujuan yang ingin dicapai dalam penelitian ini adalah : untuk mengetahui peningkatan kecerdasaan logika matematika melalui permainan kartu angka pada anak kelompok B TK Pembina Bangkinang Kota.

Berdasarkan kajian teori dan kerangka berpikir di atas, peneliti mengajukan hipotesis sebagai berikut: Permainan Kartu Angka dapat meningkatkan kemampuan kecerdasaan logika matematika pada anak Kelompok B TK Pembina Bangkinang Kota.

\section{METODE PENELITIAN}

Penelitian ini dilaksanakan anak kelompok B di TK Pembina Bangkinang Kota. Jumlah anak 20 orang yang terdiri dari 12 orang anak laki-laki dan 8 orang anak perempuan penelitian dilaksanakan pada tahun pelajaran 2015/2016. Jenis penelitian yang digunakan dalam penelitian ini adalah Penelitian Tindakan Kelas.

Penelitian dilakukan pada semester ganjil tahun ajaran 2015/2016 dan dilakukan pada saat pembelajaran berlangsung.

Jenis penelitian merupakan penelitian tindakan kelas (Class Room/ Based Action Research) dengan peningkatan unsur rancangan untuk memungkinkan diperolehnya gambaran keefektifan tindakan yang dilakukan. Penelitian yang dilakukan peneliti termasuk Penelitian Tindakan Kelas (PTK).

Menurut Arikunto (Wiji lestari, 2012) 1) Observasi adalah suatu teknik yang dilakukan dengan cara mengadakan pengamatan secara teliti serta mencatat secara sistematis. Observasi dilakukan untuk mengumpulkan data-data untuk mengetahui data rasa percaya diri anak dengan melakukan pengamatan secara 
langsung. Observasi yang dilakukan untuk pencapaian indikator yang telah ditetapkan dengan menggunakan metode bermain peran. 2) Catatan lapangan adalah beberapa catatan yang diperoleh penelitian mengenai hasil pengamatan pada saat penelitian untuk mendapatkan data yang detail mungkin, sehingga proses penelitian dapat berjalan dengan secara efektif dan efisien dalam setiap tindakan - tindakan pada saat proses belajar mengajar berlangsung. Jadi catatan lapangan dalam penelitian ini digunakan untuk merangkum perubahan - perubahan dalam proses pembelajaran yang tidak terdapat dalam pedoman observasi, sehingga catatan lapangan hanya pelengkap data. Catatan lapangan ini berisi nama guru, tempat penelitian, tanggal, waktu, kegiatan guru, dan kegiatan yang diberikan kepada anak.

Adapun langkah-langkah yang ditempuh adalah perencanaan tindakan dengan menyiapkan media dan metode pembelajaran dalam penelitian yang saling berhubungan. Media yang digunakan yaitu kartu bilangan dalam bentuk yang nyata melalui bermain. Disini guru harus dapat menciptakan suasana bermain anak yang menarik serta menyenangkan, mempersiapkan waktu yang dibutuhkan dalam pembelajaran. Dalam pelaksanaan tindakan peneliti melakukan observasi selama pembelajaran dan memperhatikan respon anak pada saat bermain Kartu bilangan dalam meningkatkan kecerdasan logika-matematika anak. Peneliti melakukan pengamatan dengan mencatat semua hal yang diperlukan dan terjadi selama pelaksanaan tindakan berlangsung. Hal ini dilakukan untuk mengetahui masalah yang sesungguhnya dan menentukan langkah yang akan diambil untuk mengatasi masalah. Refleksi dalam tindakan kelas adalah upaya untuk mengkaji apa yang telah terjadi, apa yang telah dihasilkan dan yang belum berhasil dituntaskan dengan tindakan. Hasil refleksi ini digunakan untuk menentukan tindakan lebih lanjut dalam upaya mencapai tujuan penelitan tindakan kelas. Dengan kata lain, refleksi merupakan pengkajian terhadap keberhasilan atau kegagalan dalam mencapai tujuan sementara. Refleksi ini dilakukan setiap akhir siklus penelitian.

\section{Metode Pengumpulan Data}

Untuk mengumpulkan data tentang hasil belajar permainan kartu angka anak dalam pembelajaran yang dilakukan ada beberapa teknik pengumpulan data. Dalam penelitian ini teknik yang digunakan adalah

1. Observasi

a. Untuk mengamati aktivitas guru selama penerapan permainan kartu angka.

b. Untuk mengamati aktivitas anak selama penerapan permainan kartu angka.

2. Dokumentasi

Dokumentasi digunakan untuk mengetahui sejarah sekolah, keadaan guru dan anak, sarana dan prasarana yang ada di sekolah tersebut.

3. Tes

Pemberian tes kepada anak untuk mengetahui hasil belajar permainan kartu angka.

Kegiatan mengenal konsep bilangan efektif apabila memberikan kesempatan kepada anak untuk melakukan apa yang telah diperagakan oleh guru sehingga pembelajaran tidak abstrak. Penilaian yang digunakan oleh peneliti sebagai berikut:

1. BSH : berkembang sesuai harapan yaitu apabila anak telah mampu melakukan kegiatan yang diberikan oleh guru dengan nilai 81-100.

2. MM : mulai muncul yaitu apabila anak telah melakukan kegiatan yang diberikan oleh guru namun tidak dengan benar dengan nilai 61-80.

3. BM : belum muncul yaitu apabila anak belum melakukan kegiatan yang diberikan oleh guru dengan nilai persentase $<60$

Indikator keberhasilan tindakan terdapat peningkatan kemampuan berhitung anak di taman kanak-kanak kelompok B TK Pembina Bangkinang Kota adalah apabila terdapat peningkatan kemampuan berhitung kelompok B taman kanak-kanak Pembina Bangkinang Kota tercapai secara 
individu $70 \%$ dan secara klasikal sebesar $75 \%$ dalam pembelajaran.

Data yang dihasilkan merupakan data yang dikumpulkan langsung dari anak didik dan guru baik melalui observasi, maupun catatan lapangan.

Instrumen adalah alat bantu yang dipakai dalam mengumpulkan data itu. Instrumen yang digunakan dalam penelitian ini adalah Pedoman observasi, catatan lapangan dan dokumentasi.

a. Lembar observasi peningkatan kecerdasan logika-matematik anak

b. Lembar observasi penerapan bermain kartu angka

c. Catatan lapangan Catatan lapangan adalah beberapa catatan yang diperoleh peneliti mengenai hasil pengamatan pada saat penelitian untuk mendapatkan data yang sedetail mungkin.

Teknik analisis data merupakan prosedur penelitian yang digunakan untuk proses agar data mempunyai makna untuk menjawab masalah penelitian ini dan menguji hipotesis. Tindakan analisis tersebut dilakukan secara deskriptif dengan menggunakan teknik persentase. Analisis data yang dilakukan secara deskriptif bertujuan untuk menggambarkan data tentang kemampuan anak selama proses belajar, kemudian dikategorikan dalam klasifikasi sangat baik, baik, kurang baik. Menurut (Sudjono, 2009:43), adapun dalam proses pengolahan data untuk melihat peningkatan persentase hasil tindakan digunakan rumus sebagai berikut :

Keterangan :

$$
P=\frac{F}{N} \times 100 \%
$$

$\mathrm{P}=$ Nilai yang sedang dicari persentasenya

$\mathrm{F}=$ Jumlah skor dari item atau soal yang dijawab benar

$\mathrm{N}=\quad$ Skor maskimum dari tes tersebut

$100 \%=$ Bilangan tetap

\section{HASIL DAN PEMBAHASAN}

Berdasarkan hasil observasi peningkatan kecerdasaan logika matematika anak yang dilakukan guru melalui kartu angka yang diamati dapat di peroleh hasil sebagai berikut yaitu dibawah KKM yang ditentukan.

Tabel 1. Belajar Anak Kelompok B

Menggunakan Kartu Angka

\begin{tabular}{|c|c|c|c|}
\hline Nilai & Ketuntasan & $\begin{array}{c}\text { Jumlah } \\
\text { Anak }\end{array}$ & $\begin{array}{c}\text { Persentase } \\
(\%)\end{array}$ \\
\hline$<70$ & $\begin{array}{c}\text { Belum } \\
\text { Tuntas }\end{array}$ & 14 & $70 \%$ \\
\hline$\geq 70$ & Tuntas & 6 & $30 \%$ \\
\hline \multicolumn{2}{|c|}{ Jumlah } & $\mathbf{2 0}$ & $\mathbf{1 0 0 \%}$ \\
\hline
\end{tabular}

Sumber : Data Hasil Tes, 2015

Berdasarkan tabel 1 di atas, terlihat jelas perbandingan antara anak yang mencapai ketuntasan belajar anak (KKM $\geq 70)$ adalah sebanyak 6 anak (30\%) dengan anak yang belum mencapai ketuntasan belajar sebanyak 14 anak (70\%) anak.

\section{Siklus I}

Tabel 2. Belajar Anak Kelompok B Menggunakan Kartu Angka

\begin{tabular}{|c|c|c|c|}
\hline Nilai & Ketuntasan & $\begin{array}{c}\text { Jumlah } \\
\text { Anak }\end{array}$ & $\begin{array}{c}\text { Persentase } \\
(\mathbf{\%})\end{array}$ \\
\hline$<70$ & $\begin{array}{c}\text { Belum } \\
\text { Tuntas }\end{array}$ & 9 & $45 \%$ \\
\hline$\geq 70$ & Tuntas & 11 & $55 \%$ \\
\hline Jumlah & $\mathbf{2 0}$ & $\mathbf{1 0 0 \%}$ \\
\hline
\end{tabular}

Sumber : Data Hasil Tes, 2015

Berdasarkan tabel 2 di atas, terlihat jelas perbandingan antara anak yang mencapai ketuntasan belajar anak $(\geq 70)$ adalah sebanyak 11 anak (55\%) dengan anak yang belum mencapai ketuntasan belajar anak sebanyak 9 (45\%).

Hal ini berarti tujuan penelitian secara klasikal belum $75 \%$ mencapai Kriteria Ketuntasan Minimun yang telah ditetapkan yaitu 70. Untuk itu melalui penelitian ini peneliti akan memperbaiki kegagalan yang dialami anak melalui Penelitian Tindakan Kelas dengan melakukan tindakan pada siklus kedua.

\section{Siklus II}

Dari hasil pelaksanaan pada siklus I ternyata belum mencapai tujuan penelitian maka peneliti melanjutkan penelitian pada siklus II yang dilaksanakan sebanyak 2 
kali pertemuan. Pertemuan pertama pada tanggal 17 Maret 2015 dan pertemuan kedua tanggal 25 Maret 2015.

\section{Tabel 3. Hasil Belajar Anak Kelompok B Menggunakan Kartu Angka}

\begin{tabular}{|c|c|c|c|}
\hline Nilai & Ketuntasan & $\begin{array}{c}\text { Jumlah } \\
\text { Anak }\end{array}$ & $\begin{array}{c}\text { Persentase } \\
(\%)\end{array}$ \\
\hline$<70$ & $\begin{array}{c}\text { Belum } \\
\text { Tuntas }\end{array}$ & 4 & $20 \%$ \\
\hline$\geq 70$ & Tuntas & 16 & $80 \%$ \\
\hline \multicolumn{2}{|l|}{ Jumlah } & $\mathbf{2 0}$ & $\mathbf{1 0 0 \%}$ \\
\hline
\end{tabular}

Sumber : Data Hasil Tes, 2014

Berdasarkan tabel 3 di atas, terlihat jelas perbandingan antara anak yang mencapai ketuntasan belajar anak $(\geq 70)$ adalah sebanyak 16 anak (80\%) dengan anak yang belum mencapai ketuntasan belajar anak sebanyak $4(20 \%)$ anak.

Hal ini berarti ketuntasan belajar anak kelompok B TK Pembina Bangkinang Kota secara klasikal telah $75 \%$ mencapai kriteria yang telah ditetapkan yaitu 70 . Untuk itu peneliti tidak perlu melakukan tindakan pada siklus berikutnya, karena sudah jelas hasil belajar anak telah mencapai target yang telah ditetapkan.

\section{PEMBAHASAN}

Hasil penelitian peningkatan kecerdasaan logika matematika anak kelompok $\mathrm{B}$ dengan menggunakan kartu angka di TK Pembina Bangkinang Kota, diperlukan pembahasan guna menjelaskan dan memperdalam kajian dalam penelitian ini.

Berdasarkan hasil refleksi menunjukkan adanya perubahan kemampuan belajar anak TK Pembina Bangkinang Kota yang signifikan setelah pembelajaran memahami konsep bilangan diupayakan dengan menggunakan metode kartu angka yang berupa permainan kartu bilangan. Hal ini nampak pada tabel 4 tentang perbandingan distribusi skor yang diperoleh dari keadaan prasiklus, siklus I dan siklus II berikut ini :
Tabel 4.

Perbandingan Distribusi Nilai Antara Prasiklus, Siklus I dan Siklus I

\begin{tabular}{|c|c|c|c|c|c|c|}
\hline \multirow{2}{*}{ Nilai } & \multicolumn{2}{|l|}{ Prasiklus } & \multicolumn{2}{l|}{ Siklus I } & \multicolumn{2}{l|}{ Siklus II } \\
\cline { 2 - 7 } & F & \% & F & \% & F & \% \\
\hline 50 & 5 & $25 \%$ & 1 & $5 \%$ & - & - \\
\hline 60 & 9 & $45 \%$ & 8 & $40 \%$ & 4 & $20 \%$ \\
\hline 70 & 5 & $25 \%$ & 8 & $40 \%$ & 9 & $45 \%$ \\
\hline 80 & 1 & $5 \%$ & 3 & $15 \%$ & 5 & $25 \%$ \\
\hline 90 & - & - & - & - & 2 & $10 \%$ \\
\hline 100 & - & - & - & - & - & - \\
\hline Jumlah & $\mathbf{2 0}$ & $\mathbf{2 0}$ & $\mathbf{2 0}$ \\
\hline Ketuntasan & \multicolumn{3}{|l|}{$30 \%$} & $\mathbf{5 5 \%}$ & $\mathbf{8 0 \%}$ \\
\hline
\end{tabular}

Sumber : Data Hasil Tes, 2015

Berdasarkan tabel 4 menunjukkan kenaikan besarnya nilai minimal yakni pada prasiklus dan siklus I 50 meningkat menjadi 60. Nilai maksimal pun juga mengalami kenaikan dari 80 , naik menjadi 90 pada siklus II. Jumlah anak terbanyak $5 \%$ memperoleh nilai maksimal 80 pada prasiklus, begitu pula yang fluktuatif. Jadi pemberian pada siklus I sejumlah $15 \%$ anak memperoleh nilai yang tinggi 80 , dan pada siklus II sejumlah $25 \%$ anak memperoleh nilai 80. Capaian nilai baik pada prasiklus, siklus I dan siklus II sama yakni 80, dengan persentase tindakan penggunaan kartu angka, dapat meningkatkan kecerdasaan logika matematika dengan menggunakan kartu angka anak kelompok B TK Pembina Bangkinang Kota melalui kenaikan nilai minimal dan kenaikan nilai maksimal. Begitu pula ketuntasan anak juga mengalami kenaikan yang tajam yakni dari $30 \%$, meningkat menjadi $55 \%$ dan meningkat lagi $80 \%$.

\section{KESIMPULAN}

Disimpulkan bahwa peningkatan kecerdasaan logika matematika dengan menggunakan kartu angka di TK Pembina Bangkinang Kota, sebelum ada perbaikan pembelajaran (tindakan) menunjukkan kecerdasaan logika matematika rendah. Hal ini ditunjukkan adanya ketuntasan dengan kartu angka sebesar $30 \%$ yang berada di bawah nilai < 70, dan skor tertinggi 80 dan skor terendah 
50.Kecerdasaan logika matematika dengan menggunakan kartu angka anak meninggkat setelah ada perbaikan pembelajaran melalui metode kartu angka dalam meningkatkan kecerdasaan logika matematika, yang ditunjukkan oleh kenaikan nilai menjadi $55 \%$ pada siklus I dan $80 \%$ pada siklus II.

\section{UCAPAN TERIMAKASIH}

Dengan selesainya penelitian dan terwujudnya artikel jurnal ini tentu tidak terlepas dari bantuan berbagai pihak, untuk itu perkenakanlah dalam kesempatan ini penulis menyampaikan penghargaan yang setulus-tulusnya dengan ucapan terimakasih kepada Bapak/Ibu yang telah membantu menyelesaikan artikel jurnal ini terutama pada TK Pembina Bangkinang Kota yang telah bersedia menerima peneliti untuk meneliti di TK Pembina Bangkinang Kota.

\section{DAFTAR PUSTAKA}

Asiyah, S. (2013). Penggunaan Media Kartu Angka dalam Meningkatkan Kemampuan Mengenal Konsep Bilangan pada Anak Kelompok A Tk Islam Mutiara Surabaya, (1), 1-13.

Eny Purwaningtyastuti. (2012). Meningkatkan Kecerdasan LogikaMatematika Anak melalui Bermain Balok Kelompok A Di TK An Nisa' Marditani Celep Kedawung Sragen Tahun Ajaran 2011/2012, 1-15.

Fauziddin, M. (2017). Penerapan Belajar Melalui Bermain Balok Unit untuk Meningkatkan Kreativitas Anak Usia Dini. Curricula, 1(3). https://doi.org/http://dx.doi.org/10.222 16/JCC.2016.v2i3.1277

Hartini, P. (2003). Peningkatan Kemampuan Matematika Anak Melalui Media Permainanmemancing Angka Di Taman Kanak-Kanak Fathimah Bukareh Agam. Pesona PAUD, I(20).

Peraturan menteri Kesehatan Republik Indonesia. (2015). Pedoman Stimulasi Kognitif Pada Anak Berbasis Kecerdasaan Manjemuk.
Permendiknas. (2003). Undang-Undang Republik Indonesia Sistem pendidikan Nasional.

Puspitasari, E. (2012). Pengembangan model pos paud keliling, 91-96.

Suhaidah. (2014). Meningkatkan Kecerdasan Logika Matematika Anak pada Usia Dini dengan Pengenalan Warna dan Bentuk pada Siswa Paud "Assyfah" Biaro Baru Kelompok B Tahun Pembelajaran 2013 / 2014.

Wiji lestari. (2012). Peningkatan kemampuan logika matematika anak tk $b$ melalui metode pemecahan masalah di tk 'aisyiyah bustanul athfal kauman, kecamatan cawas kabupaten klaten tahun ajaran 2011/2012 (pp. 114). 